\title{
Plant growth promoting potential of endophytic bacteria isolated from cashew leaves
}

Milca Rachel da Costa Ribeiro Lins ${ }^{1}$, Jéssica Martins Fontes ${ }^{1}$, Nataliane Marques de Vasconcelos $^{1}$, Danilo Mamede da Silva Santos ${ }^{2}$, Ozias Elias Ferreira ${ }^{3}$, João Lúcio de Azevedo ${ }^{4}$, Janete Magali de Araújo ${ }^{1}$ and Gláucia Manoella de Souza Lima ${ }^{1 *}$

${ }^{1}$ Department of Antibiotics of Universidade Federal de Pernambuco - UFPE, Avenida Prof. Moraes Rego, s/n - Cidade Universitária, CEP: 50670-901, Recife, Pernambuco, Brazil.

${ }^{2}$ Education Department of Universidade do Estado da Bahia - UNEB, Rua do Bom Conselho, 179, Alvez de Souza, CEP: 46800-000, Paulo Afonso - Bahia, Brazil.

${ }^{3}$ Federal Institute of Pernambuco - IFPE, Av. Prof. Luiz Freire, 500 - CEP 50740-540, Cidade Universitária, Recife-PE.

${ }^{4}$ Luiz de Queiroz" College of Agriculture, Universidade de São Paulo - ESALQ/USP, Av. Pádua Dias, 11 - CEP 13418900, Piracicaba, Sao Paulo, Brazil.

\begin{abstract}
Endophytic microorganisms are able to promote plant growth through various mechanisms, such as production of plant hormones and antimicrobial substances, as well as to provide the soil with nutrients, for instance, inorganic phosphate. This study aimed to evaluate the potential of endophytic bacteria isolated from cashew leaves to produce substances involved in the promotion of plant growth, such as indole-3-acetic acid, the phosphate solubilization capacity, and the antimicrobial activity. For this, 31 isolate samples were used, out of which $17(54.8 \%)$ produce indole-3-acetic acid in concentrations ranging from 11.79 to $145.85 \mu \mathrm{g} \cdot \mathrm{mL}^{-1}$. In turn, four $(12.9 \%)$ were able to solubilize phosphate and the solubilization halos range from 5 to $19 \mathrm{~mm}$. Soluble phosphorus concentrations range from 62.5 to $1,605.2 \mathrm{mg} \cdot \mathrm{L}^{-1}$. It was observed that Fusarium oxysporum and Colletotrichum sp. were inhibited by 70 and $40 \%$ of the strains, respectively. It was found out that five bacteria (25\%) were Gram-positive, predominantly the species Staphylococcus saprophyticus (100\%), while 15 bacteria (75\%) were Gram-negative. Out of these, $4(26.6 \%)$ and $3(20 \%)$ belong to the species Escherichia coli and Shigella flexneri, respectively. Studying the endophytic population is something important due its biotechnological applications, because it has a great potential for promoting plant growth.
\end{abstract}

Key words: Anacardium occidentale, auxin, endophytic microorganisms, secondary metabolites, phosphate solubilization.

\section{INTRODUCTION}

In recent decades, the search for new compounds with

applications to health and agriculture has increased and

*Corresponding author. E-mail: gmslima@yahoo.com.br. Tel: +558121268347. Fax: +558121268346.

Author(s) agree that this article remain permanently open access under the terms of the Creative Commons Attribution License $\underline{4.0 \text { International License }}$ 
in this context, endophytic microorganisms have shown a great potential, since they represent an important genetic diversity source and bioactive compounds (Zhao et al., 2010; Joseph and Priya, 2011).

Endophytes microorganisms spend at least one period of their life cycle beneficially associated to plants' tissues and/or organs, such as roots, branches, and leaves, and they can be isolated after disinfecting the surface of these plants. Bacteria and fungi, which are commonly found as endophytes, do not cause harm to their hosts; instead, they play important roles with regard to the plant's health (Azevedo et al., 2000; Azevedo et al., 2006; Nair and Padmavathy, 2014).

During a long co-evolution period, a friendly relationship was formed between endophytes and the host plant. Some endophytes can produce the same or similar bioactive compounds from the host plant, presenting a mutualistic association, as they receive nutrients, protection by the plant, and other benefits, such as pathogenic microorganism control, insect control, and protection against herbivores (Zhao et al., 2011).

These microorganisms facilitate the plant's growth and development through two mechanisms: Direct: when it involves in the supply of compounds which are synthesized and make easier the absorption of nutrients from the environment; and Indirect: when the microorganism reduces or prevents the harmful effects of pathogens by producing inhibitory substances or increasing the host's natural resistance.

The direct mechanisms are nitrogen fixation $\left(\mathrm{N}_{2}\right)$, phosphate solubilization, insoluble iron chelation through the production of siderophores and phytohormones, such as auxins, cytokinins, and gibberellins (Oliveira et al., 2003; Tsavkelova et al., 2007; Jha et al., 2012).

Auxins are hormones produced by endophytes which regulate plant growth and act on the cell division, elongation, and differentiation (Shokri and Emtiazi, 2010). However, the interaction of bacteria with the host plant for promoting growth depends on the concentration of hormones available to the plant cells (Oliveira et al., 2003).

Indole-3-acetic acid (IAA) is the most important auxin for the growth of roots and stems by stretching the cells (Tsavkelova et al., 2007). This hormone is usually produced by several bacteria genera which promote plant growth, such as Actinomyces, Agrobacterium, Arthrobacter, Azospirillum, Azotobacter, Bacillus, Burkholderia, Caulobacter, Chromobacterium, Enterobacter, Gluconacetobacter, Klebsiella, Methylobacterium, Pantoea, Pseudomonas, Rhizobium, Salmonella, Sthaphylococcus and among others (Hayat et al., 2010; Bhattacharyya et al., 2012; Oliveira et al., 2013; Zheng et al., 2013; Rangjaroen et al., 2014).

Another important function of endophytic bacteria is related to the phosphorus cycle, being responsible for the hydrolysis of phosphorus to its soluble form. These microorganisms use different mechanisms to convert forms insoluble in soluble phosphate through the activity of enzymes such as phosphatases or phosphohydrolases with processes of acidification, chelation, exchange reactions, but usually, the main mechanism of solubilization is the release of metabolites such as organic acids (Hameeda et al., 2008; Young et al., 2013).

The ability of endophytic bacteria with regard to the solubilization of inorganic phosphate raised interest in agricultural practices and because of this, the endophytic microorganisms have been studied. They play an important role in the conversion of phosphorus to soluble phosphate.

Studying the endophytic population is important not only for acquiring knowledge on its ecological role, but also with regards to its biotechnological applications to the production of bioactive substances which can be used in the field in order to increase the agricultural production. This study aimed to evaluate endophytic bacteria producing indole acetic acid and solubilized phosphorus as well as identify them by biochemical characteristics.

\section{MATERIALS AND METHODS}

\section{Microorganisms}

We used 31 endophytic bacteria from cashew leaves (Anacardium occidentale L.) that belonged to the Microorganism Collection UFPEDA, Brazil. The strains were inoculated in BHI broth (Dadook et al., 2013) for reactivation and incubated for $24 \mathrm{~h} / 30^{\circ} \mathrm{C}$. Afterwards, the biochemical characteristics were analyzed as described above.

\section{Classical taxonomy (phenotypic features and microscopic analysis)}

Bacteria were cultivated on Agar Nutrient (Verma et al., 2001) and after $24 \mathrm{~h}$, Gram staining and biochemical tests were performed using the systems Bactray I and II (Gram-negative negative oxidase) and III (Gram-negative positive oxidase), in accordance with the manufacturer's instructions (LaborClin). Gram positive bacteria were identified by specific

tests including catalase test, DNase agar, mannitol salt agar and sensitivity to novobiocin according to Winn et al. (2006).

\section{Production of indole-3-acetic acid}

The production of IAA was analyzed according to the method developed by Sarwar and Kremer (1995); inoculating 31 endophytic bacteria padronized $1.0 \times 10^{8} \mathrm{UFC} / \mathrm{ml}(\lambda=625 \mathrm{~nm})$ in tubes with $10 \%$ TSA (Kuklinsky-Sobral et al., 2004) supplemented with $5 \mathrm{mmol} . \mathrm{L}^{-1}$ of L-tryptophan and cultivated for $24 \mathrm{~h} / 30^{\circ} \mathrm{C}$ in the dark under a 110 $\times \mathrm{g}$ shake. After growth, the samples were centrifuged at $8000 \times \mathrm{g}$ for $15 \mathrm{~min}$ and to the supernatant, the reagent Salkowski $\left(0.5 \mathrm{~mol} . \mathrm{L}^{-}\right.$ ${ }^{1} \mathrm{FeCl}_{3}+7.9$ mol.L $\left.{ }^{-1} \mathrm{H}_{2} \mathrm{SO}_{4}\right)$ was added in a $1: 1$ ratio $(\mathrm{v} / \mathrm{v})$ and left in the dark for $30 \mathrm{~min}$ at room temperature. The emergence of pinkred color indicated the production of auxins. For quantifying IAA, spectrophotometer at $530 \mathrm{~nm}$ was used. A standard curve was obtained with commercial IAA solutions (Vetec) at different concentrations. Tests were performed in triplicate and Pantoea agglomerans UFPEDA 774 was used as the positive control and 
Table 1. Concentration of indole-3-acetic acid produced by endophytic bacteria of cashew leaves.

\begin{tabular}{lccc}
\hline Bacterial strain & Concentration of IAA $\left(\boldsymbol{\mu g} \cdot \mathbf{m L}^{-1}\right)$ & Bacterial Strain & Concentration of IAA $\left(\boldsymbol{\mu} \mathbf{g} \cdot \mathbf{m L}^{-1}\right)$ \\
\hline Pantoea agglomerans & $76.31 \pm 4.15$ & BC-26 & $37.29 \pm 9.00$ \\
BC-1 & $23.12 \pm 3.24$ & BC-46 & $132.79 \pm 3.53$ \\
BC-2 & $36.95 \pm 4.64$ & BC-47 & $131.73 \pm 17.58$ \\
BC-8 & $144.43 \pm 0.50$ & BC-48 & $130.7 \pm 6.49$ \\
BC-9 & $38.81 \pm 0.23$ & BC-49 & $106.63 \pm 0.22$ \\
BC-10 & $145.85 \pm 0.44$ & BC-51 & $11.79 \pm 2.81$ \\
BC-21 & $135.29 \pm 0.00$ & BC-55 & $108.91 \pm 14.67$ \\
BC-22 & $132.79 \pm 3.53$ & BC-63 & $104.29 \pm 13.17$ \\
BC-24 & $16.66 \pm 4.68$ & BC-147 & $62.07 \pm 0.31$ \\
\hline
\end{tabular}

\pm Standard deviation.

the negative control consisted of the same medium supplemented with L-tryptophan, with no bacterial growth.

\section{Evaluation of inorganic phosphate solubilization}

For the semiquantitative assessment of phosphate solubilization, the bacteria $\left(1.0 \times 10^{8} \mathrm{UFC} / \mathrm{ml}, \lambda 625 \mathrm{~nm}\right)$ were inoculated in spots on plates containing three different media: 'National Botanical Research Institute's Phosphate Solubilization' - NBRIP (Kumar et al., 2012); the medium according to Verma et al. (2001) and Phosphate medium (Kuklinsky-Sobral et al., 2004). After $120 \mathrm{~h}$ of incubation, clear zones around the colonies were indicative of solubilization of inorganic phosphate and the phosphate solubilization index (PSI) was calculated according to Sarkar et al. (2012). P. agglomerans UFPEDA 774 was used as the positive control.

\section{Evaluation of phosphate solubilization in liquid medium}

Each strain containing $1.0 \times 10^{8} \mathrm{UFC} / \mathrm{ml}(\lambda 625 \mathrm{~nm})$, were inoculated on NBRIP and VERMA medium (previously described), according to Kumar et al. (2012) and Verma et al. (2001). After 144 $\mathrm{h}$, the supernatants were analysed according molybdate-vanadate method (Inui-Kishi et al., 2012). Afterwards, the absorbance was estimated the absorbance at $420 \mathrm{~nm}$. A standard curve was obtained from potassium phosphate solutions (1.0; $2.0 ; 4.0 ; 5.0$; $6.0 ; 8.0 ; 10.0 \mathrm{mg}^{-1}$ ) in accordance with the Standard Methods (Clesceri et al., 1999). P. agglomerans UFPEDA 774 was used as the positive control.

\section{Statistical analyses}

Each experiment was performed in triplicate and analysis of variance was performed (ANOVA) at $p \leq 0.05$ and the Tukey test ( $p$ $\leq 0.05$ ) on the program Excel 2010 and Minitab version 15 to analyze the results of IAA's production, semiquantitative and quantitative phosphate solubilizing on VERMA and NBRIP media by bacteria of Cashew tree was done (Bluman, 2001).

\section{Antimicrobial activity}

The solubilizing phosphate and/or producing IAA strains were tested against the activity of $A$. niger UFPEDA 2003, Colletotrichum sp. UFPEDA 2561 and F. oxysporum UFPEDA $2456\left(1.0 \times 10^{6}\right.$ spores $/ \mathrm{mL}$ ). The fungi were inoculated on potato dextrose agar (Ribeiro and Cardoso, 2012) and the antagonistic activity was evaluated after seven days at $28^{\circ} \mathrm{C}$.

\section{RESULTS AND DISCUSSION}

\section{Production of IAA and quantitative assessment}

Out of the 31 strains tested with regards to the production of auxin, 17 (54.83\%) showed reddish pink coloration after addition of the reagent Salkowski, indicating that they produce IAA through tryptophan, with concentrations ranging from 11.79 to $145.85 \mu \mathrm{g} \cdot \mathrm{mL}^{-1}$ (Table 1 ).

The plant hormone production is part of the metabolism of several microorganisms associated to plants and they may be regarded as important agents in the regulation of the plant's growth and development (Oliveira et al., 2003). The auxin synthesized by bacteria affects the root system by increasing the number and size of adventitious roots (Gutierrez et al., 2012). One should take into account the fact that the IAA effect may vary according to their concentrations. Depending on the plant's variety, higher concentrations of IAA can have an inhibiting effect on plant growth inducing callus tissues (Ribeiro and Cardoso, 2012).

The colorimetric method for observing the production of auxins by microorganisms uses the reagent Salkowski and it is based on the oxidation of indole compounds by ferric salts (Mayer, 1958). Variation in the concentration of auxin produced by the endophytic bacteria may have been caused by differences in the behavior of each bacterium, and one needs to better understand the IAA synthesis at different times of bacterial growth, thus determining the time when the maximum synthesis of the product took place.

ANOVA indicated that the averages obtained in relation to production of IAA are not statistically equal $(p>0.05)$. Then, the Tukey shows the strain BC-10 has good potential to produce this important metabolite for plants growth. 
Table 2. Phosphate solubilization index (PSI) of solubilized phosphorus in plate assay of endophytic bacteria.

\begin{tabular}{lccc}
\hline Bacterial strain & VERMA & NBRIP & Phosphate medium \\
\hline BC-51 & - & - & $2.85 \pm 0.51$ \\
BC-52 & - & - & $1.9 \pm 0.09$ \\
BC-53 & $2.21 \pm 0.21$ & $2.29 \pm 0.66$ & $2.31 \pm 0.09$ \\
BC-56 & $1.54 \pm 0.04$ & $1.83 \pm 0.14$ & $3.92 \pm 0.09$ \\
P. agglomerans & $3.02 \pm 0.42$ & $2.00 \pm 0.00$ & $2.19 \pm 0.26$ \\
\hline
\end{tabular}

\pm Standard deviation.

Table 3. Concentration (mg. $\mathrm{L}^{-1}$ ) of phosphorus solubilized by endophytic bacteria of cashew leaves.

\begin{tabular}{lc}
\hline Bacterial strain (media) & Concentration of solubilized phosphate $\left(\mathbf{m g}_{\mathbf{~}} \mathbf{L}^{\mathbf{1}}\right.$ ) \\
\hline BC-51 (NBRIP) & $36.73 \pm 1.00$ \\
BC-51 (VERMA) & $126.89 \pm 21.00$ \\
BC-52 (NBRIP) & $113.53 \pm 15.99$ \\
BC-52 (VERMA) & $400.70 \pm 25.05$ \\
BC-53 (NBRIP) & $1569.41 \pm 11.00$ \\
BC-53 (VERMA) & $1349.02 \pm 62.31$ \\
BC-56 (NBRIP) & $1389.09 \pm 62.31$ \\
BC-56 (VERMA) & $1395.77 \pm 32.17$ \\
Pantoea agglomerans (NBRIP) & $1095.25 \pm 84.00$ \\
Pantoea agglomerans (VERMA) & $808.08 \pm 34.28$ \\
\hline
\end{tabular}

\pm Standard deviation.

Kuklinsky-Sobral et al. (2004) observed that $34 \%$ of the endophytic bacteria associated to soybean are auxin producers, standing out in the production of important substances for promoting plant growth. In this study, the $\mathrm{BC}-10$ isolate showed auxin production with a 145.85 $\mu \mathrm{g} \cdot \mathrm{mL}^{-1}$ concentration, higher than the result obtained by Kochar et al. (2011) through the $P$. fluorescens isolate $\left(25.82 \mu \mathrm{g} \cdot \mathrm{mL}^{-1}\right)$ in a culture medium containing the same tryptophan concentration $\left(5 \mathrm{mmol} . \mathrm{L}^{-1}\right)$.

Therefore, the results found in the literature corroborate those obtained through the endophytic bacteria of cashew leaves analyzed in this study.

\section{Phosphate solubilization assessment}

The tested bacteria showed low phosphate solubilization, only 4 strains $(12.9 \%)$ were able to solubilize phosphorus in the Phosphate medium (BC-52, BC-53, BC-56, and $B C-51$ ), highlighting the strain $B C-51$ which also produces IAA. Only two out of the four strains were able to solubilize phosphate in the VERMA and NBRIP media.

The PSI was calculated through the ratio between the phosphate solubilization halo $(\mathrm{mm})$ and the colony diameter $(\mathrm{mm})$, and it was observed that it ranged from 1.90 to 3.92 in the Phosphate medium and, among the four strains, three (BC-51, BC-53, and BC-56) showed a phosphate solubilization higher than the positive control, $P$. agglomerans. In the VERMA medium, PSI ranged from 1.53 to 2.21 and in NBRIP it ranged from 1.83 to 2.29 (Table 2).

After analyses of variance, it was cleared that the averages of PSI are not statistically equal $(p>0.05)$ in relation to phosphate solubilization in solid media with phosphate insoluble.

Regarding the phosphate solubilization, according to Chagas-Junior et al. (2010), the PSI is measured through the ratio solubilization halo $(\mathrm{mm}) /$ colony diameter $(\mathrm{mm})$. Thus, the solubilization may be classified as low solubility (PSI < 2), middle solubilization $(2 \leq \mathrm{PSI}<4)$, and high solubility (PSI $>4)$. Then, all of the endophytic bacteria of cashew tree have low or medium capability to solubilize phosphate.

The phosphorus concentrations solubilized by the isolates ranged from 36.73 to $1,569.41 \mathrm{mg} \cdot \mathrm{L}^{-1}$. The strains $\mathrm{BC}-53$ and $\mathrm{BC}-56$ solubilized phosphate at a higher concentration than the positive control in the NBRIP and VERMA media (Table 3). In liquid media, the $p$-value of ANOVA was less than 0.05 showing that there was difference between the averages of phosphate solubilization in liquid media. The Turkey test indicated that BC-53, BC-56 and the control P. agglomerans have 
Table 4. Identification of endophytic bacterial strains which produced IAA and solubilized phosphate.

\begin{tabular}{clcl}
\hline Bacterial strain & Species & Bacterial strain & Species \\
\hline BC-1 & Staphylococcus saprophyticus & BC-47 & E. coli \\
BC-2 & S. saprophyticus & BC-48 & E. coli \\
BC-8 & Shigella flexneri & BC-49 & E. coli \\
BC-9 & S. flexneri & BC-51 & Enterobacter cloacae \\
BC-10 & S. flexneri & BC-52 & Pseudomonas maltophilia \\
BC-21 & Yersinia psedotuberculosis & BC-53 & Escherichia fergusonii \\
BC-22 & Escherichia coli & BC-55 & Pseudomonas stutzeri \\
BC-24 & S. saprophyticus & BC-56 & Enterobacter sakazakii \\
BC-26 & S. saprophyticus & BC-63 & S. saprophyticus \\
BC-46 & Klebsiella sp. & BC-147 & Hafnia alvei \\
\hline
\end{tabular}

the same capability to solubilize phosphate and they had higher concentrations of soluble phosphorus than BC-51 and BC-52.

The changes observed in the soluble phosphorus concentration are due to the features and requirements of each bacterial growth, for instance, different nutrient compositions in the culture medium influence the microbial development. Sarkar et al. (2012) isolated bacteria from roots of rice seedlings and tested the phosphate solubilization ability in a Pikovskaya liquid media and the concentrations ranged from 87.8 to 140.1 $\mathrm{mg} \cdot \mathrm{L}^{-1}$. For this reason, the endophytic bacteria of cashew leaves have higher concentrations of soluble phosphate and because of this, they have characteristics that might promote plant growth.

\section{Antimicrobial activity assessment}

Out of the 20 endophytic bacteria which produced auxin and/or solubilized phosphate, did not observe an antimicrobial activity against $A$. niger UFPEDA 2003 was not observed. However, $14(70 \%)$ showed activity against F. oxysporum UFPEDA 2456 , while eight $(40 \%)$ showed activity against Colletotrichum sp. UFPEDA 2561.

Regarding the antimicrobial activity, the term antagonist is used for the biological agents with potential to interfere in the life processes of pathogenic microorganisms, inhibiting their growth. Further studies with a deeper investigation involving biological control are needed, since the endophytic bacteria can show an activity against other pathogen types.

\section{Characterization of classical taxonomy}

Biochemical characterization showed that five $(25 \%)$ are Gram-positive bacteria and the results suggest that all of them belong to species S. saprophyticus. It was found that $15(75 \%)$ are Gram-negative bacteria and, among the Gram-negative bacteria with negative oxidase, it was suggested that $26.6 \%$ belong to the species $E$. coli and $20 \%$ S. flexneri. Other species, such as $E$. fergusoni, $H$. alvei, Y. pseudotuberculosis, and those from the genus Klebsiella sp were observed. Among the Gram-negative bacteria with positive oxidase, species $E$. cloacae, $P$. maltophilia, and $P$. stutzeri (Table 4) were observed. However, the confirmation with molecular tools needs to be done.

Stamford et al. (1998) identified the genus Staphylococcus as endophytic of yam bean. A similar phenomenon was observed by Velásquez et al. (2008), who were also able to identify the genus Staphylococcus as being endophytic of sugar cane through the analysis of $16 \mathrm{~S}$ rRNA. Vendan et al. (2010) also identified endophytic bacteria from ginseng and observed that the genus Staphylococcus, confirm the results obtained in this study.

Several studies reported the occurrence of enterobacteria as plant endophytes. The presence of these microorganisms, such as Klebsiella spp., is usually observed in the endophytic community playing important roles in the host plants, since they are able to produce phytohormones and provide nitrogen (Dong et al., 2003; Durán et al., 2014; Guo et al., 2014).

The genus Pseudomonas and Burkholderia was identified as endophytic through biochemical and molecular tools; also they had the ability to produce some phytohormones and solubilized phosphate to growth plant (Mendes et al., 2007; Chauhan et al., 2013; Allu et al., 2014).

The assessed strains have higher potential for promoting plant growth and/or being used as biofertilizers through the production of phytohormones, such as auxins, as well as the conversion of insoluble phosphorus into soluble one, making it accessible to plant absorption. Therefore, research involving endophytes which have more than one feature for promoting plant growth is important for a better understanding of their interaction with the plant, something useful for analyzing the use of microorganisms in agriculture. 


\section{Conflict of Interests}

The author(s) have not declared any conflict of interest.

\section{REFERENCES}

Allu S, Kumar NP, Audipudi AV (2014). Isolation, biochemical and PGP characterization of endophytic Pseudomonas aeruginosa isolated from chilli red fruit antagonistic against chilli anthracnose disease. Int. J. Curr. Microbiol. App. Sci. 3(2):318-329.

Azevedo JL, Araújo WL, Lacava PT, Andreote FD (2006). Caracterização da comunidade bacteriana endofítica de citros por isolamento, PCR específico e DGGE. Pesqui. Agropec. Bras. 41:637642.

Azevedo JL, Maccheroni-Jr W, Pereira JO, Araújo WL (2000). Endophytic microorganisms: a review on insect control and recent advances on tropical plants. Electr. J. Biotechn. 3:40-65.

Bhattacharyya PN, Jha DK (2012). Plant growth-promoting rhizobacteria (PGPR): emergence in agriculture. World J. Micro. Biot. 28:1327-1350.

Bluman AG (2001). Elementary statistics: a step by step approach. 4th ed. chapter 13.

Chagas-Junior AF, Oliveira LA, Oliveira AN, Willerding AL (2010). Capacidade de solubilização de fosfatos e eficiência simbiótica de rizóbios isolados de solos da Amazônia. Acta Sci. Agron. 32(2):359366.

Chauhan H, Bagyaraj DJ, Sharma A (2013). Plant growth-promoting bacterial endophytes from sugarcane and their potential in promoting growth of the host under field conditions. Exp Agri 49(1):43-52.

Clesceri LS, Greenberg AE, Eaton AD (1999). Standard methods for the examination of water and wastewater, 20th ed.

Dadook M, Mehrabian S, Irian S (2013). Identification of ten N2-fixing bacteria using 16S rRNA and their response to various zinc concentrations. Inter. J. Cell. Mol. Biotech. 1-8.

Dong Y, Iniguez AL, Triplett EW (2003). Quantitative assessments of the host range and strain specificity of endophytic colonization by Klebsiella pneumoniae 342. Plant Soil 257:49-59.

Durán P, Acuña JJ, Jorquera MA, Azcón R, Paredes C, Rengel Z, Mora ML (2014). Endophytic bacteria from selenium-supplemented wheat plants could be useful for plant-growth promotion, biofortification and Gaeumannomyces graminis biocontrol in wheat production. Biol. Fert. Soils 50(6):983-990.

Guo C, Sun L, Kong D, Sun M, Zhao K (2014). Klebsiella variicola, a nitrogen fixing activity endophytic bacterium isolated from the gut of Odontotermes formosanus. Afr. J. Micrbiol. Res. 8(12):1322-1330.

Gutierrez L, Mongelard G, Floková K, Păcurar DI, Novák O, Staswick P, Kowalczyk M, Păcurar M, Demailly H, Geiss G, Bellinid C (2012). Auxin controls Arabidopsis adventitious root initiation by regulating jasmonic acid homeostasis. Plant Cell 24:2515-2527.

Hameeda B, Harini G, Rupela, OP, Wani, SP, Reddy G (2008). Growth promotion of maize by phosphate-solubilizing bacteria isolated from composts and macrofauna. Microbiol. Res. 163(2):234-242.

Hayat R, Ali S, Amara U, Khalid R, Ahmed I (2010). Soil beneficial bacteria and their role in plant growth promotion: a review. Ann. Microbiol. 60:579-598.

Inui-Kishi RN, Kishi LT, Picchi SC, Barbosa JC, Lemos MTO, Marcondes J, Lemos EGM (2012). Phosphorus solubilizing and IAA production activities in plant growth promoting rhizobacteria from brazilian soils under sugarcane cultivation. J. Eng. Appl. Sci. 7(11):1446-1454

Jha B, Gontia I, Hartmann A (2012). The roots of the halophyte Salicornia brachiata are a source of new halotolerant diazotrophic bacteria with plant growth-promoting potential. Plant Soil 356:265277.

Joseph B, Priya RM (2011). Bioactive compounds from endophytes and their potential in pharmaceutical effect: a review. Am. J. Biochem. Mol. Biol. 1(3):291-309.

Kochar M, Upadhyay A, Srivastava S (2011). Indole-3-acetic acid biosynthesis in the biocontrol strain Pseudomonas fluorescens Psd and plant growth regulation by hormone overexpression. Res.
Microbiol. 162:426-435

Kuklinsky-Sobral J, Araújo WL, Mendes R, Geraldi IO, Pizzirani-Kleiner AA, Azevedo JL (2004). Isolation and characterization of soybeanassociated bacteria and their potential for plant growth promotion Environ. Microbiol. 6:1244-1251.

Kumar P, Dubey RC, Maheshwari DK (2012). Bacillus strains isolated from rhizosphere showed plant growth promoting and antagonistic activity against phytopathogens. Microbiol. Res. 167:493-499.

Mayer AM (1958). Determination of indole acetic acid by the Salkowsky reaction. Nature 162:1670-1671.

Mendes R, Pizzirani-Kleiner AA, Araújo WL, Raaijmakers JM (2007). Diversity of cultivated endophytic bacteria from sugarcane: genetic and biochemical characterization of Burkholderia cepacia complex isolates. Appl. Environ. Microbiol. 73:7259-7267.

Nair DN, Padmavathy S (2014). Impact of endophytic microorganisms on plants, environment and humans. Scientific World J.

Oliveira ALM, Urquiaga S, Baldani JI (2003). Processos e mecanismos envolvidos na influência de microrganismos sobre o crescimento vegetal. Embrapa Agrobiologia Documentos 161:1-5.

Oliveira MNV, Santos TMA, Vale HMM, Delvaux JC, Cordero AP, Ferreira AB, Miguel PSB, Tótola MR, Costa MD, Moraes CA, Borges AC (2013). Endophytic microbial diversity in coffee cherries of Coffea arabica from southeastern Brazil. Can. J. Microbiol. 59(4):221-230.

Rangjaroen C, Rekarsem B, Teaumroong N, Noisangiam R, Lumyong S (2014). Promoting plant growth in a commercial rice cultivar by endophytic diazotrophic bacteria isolated from rice landraces. Ann. Microbiol. 1-14.

Ribeiro CM, Cardoso EJBN (2012). Isolation selection and characterization of root-associated growth promoting bacteria in Brazil Pine (Araucaria angustifolia). Microbiol. Res. 167:69-78.

Sarkar A, Islam T, Biswas GC, Alam S, Hossain M, Talukder NM (2012). Screening for phosphate solubilizing bacteria inhabiting the rhizoplane of rice grown in acidic soil in Bangladesh. Acta Microbiol. Imm. H. 59:199-213.

Sarwar M, Kremer RJ (1995). Determination of bacterially derived auxins using a microplate method. Lett. Appl. Microbiol. 20:282-285.

Stamford TLM, Araújo JM, Stamford NP (1998). Atividade enzimática de microrganismos isolados do jacatupé (Pachyrhizus erosus L Urban). Ciênc. Tecnol. Aliment. 18:4-10.

Tsavkelova EA, Cherdyntseva TA, Botina SG, Netrusov Al (2007). Bacteria associated with orchid roots and microbial production of auxin. Microbiol. Res. 162:69-76.

Velásquez E, Rojas M, Lorite MJ, Rivas R, Zurdo-Piñeiro JL, Heydrich M, Bedmar EJ (2008). Genetic diversity of endophytic bacteria which could be found in the apoplastic sap of the medullary parenchym of the stem of healthy sugarcane plants. J. Basic Microbiol. 48:118-124.

Vendan RT, Yu YJ, Lee SH, Rhee YH (2010). Diversity of endophytic bacteria in ginseng and their potential for plant growth promotion. J. Microbiol. 48(5):559-565.

Verma SC, Ladha JK, Tripathi AK (2001). Evaluation of plant growth promoting and colonization ability of endophytic diazotrophs from deep water rice. J. Biotechnol. 91:127-141.

Winn WC, Allen S, Janda W, Koneman E, Procop G, Schreckenberger $P$ (2006). Koneman's color ctlas and textbook of diagnostic microbiology. 6 th ed. Philadelphia: Lippincott Williams and Wilkins.

Young LS, Hameed A, Peng SY, Shan YH, Wu SP (2013). Endophytic establishment of the soil isolate Burkholderia sp. CC-Al74 enhances growth and P-utilization rate in raize (Zea mays L.). Appl. Soil Ecol., 66:40-47.

Zhao J, Shan T, Mou Y, Zhou L (2011). Plant-derived bioactive compounds produced by endophytic fungi. Mini Rev. Med. Chem. 11:159-168.

Zhao J, Zhou L, Wang J, Shan T, Zhong L, Liu X, Gao X (2010). Endophytic fungi for producing bioactive compounds originally from their host plants. Curr. Res., Technol. Educ. Trop. Appl. Microbiol. Microbial. Biotechnol. 1:567-576.

Zheng J, Allarda S, Reynoldsb S, Millnerb P, Arcea G, Blodgetta RJ, Browna EW (2013). Colonization and internalization of Salmonella enterica in tomato plants. Appl. Environ. Microbiol. 79(8):2494-2502. 